\title{
STATELESSNESS IN THE EUROPEAN UNION: EXPLORING THE POTENTIAL VALUE OF UNION CITIZENSHIP
}

\begin{abstract}
ANNE BREKOO*
Nearly half a million people find themselves stateless within the Member States of the European Union. Lacking an overarching mechanism to address statelessness and its consequences at the EU level, the problem remains. In a different citizenship context, however, the EU has demonstrated that it is capable of devising a framework of rights that transcends national boundaries: citizenship of the EU. With the aim of inspiring renewed debates on, and reconsideration of, the institution of EU citizenship as a potential approach to mitigating the human impact of statelessness, this article examines the value that EU citizenship might have for stateless persons.
\end{abstract}

\section{TABLE OF CONTENTS}

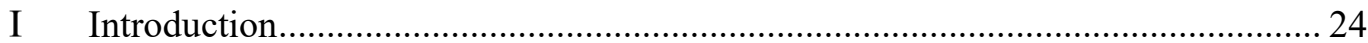

II Concepts and Definitions: Statelessness, Nationality and Citizenship ...................226

III Statelessness in the EU and the Potential Value of EU Citizenship .......................2 29

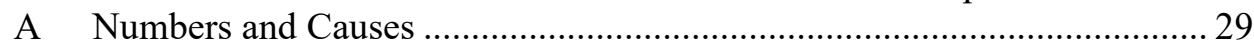

B EU Citizenship: Scope and Nature ........................................................... 32

C The Impact of Statelessness and the Value of EU Citizenship.................... 34

IV Moving from the Hypothetical to Reality: An Assessment .....................................39

A The Competence Question ........................................................................... 39

B Realising a Reformed EU Citizenship: Possibilities and Obstacles ........... 40

V Conclusion 41

\section{INTRODUCTION}

Statelessness, referring to the lack of a nationality, has been characterised as a 'forgotten human rights crisis', having only received limited attention from key actors on a national, regional and global level. ${ }^{1}$ The European Union constitutes, in that sense, no exception. While fundamental rights have been placed at the heart of the EU, and the individual at the heart of its activities by means of EU citizenship, ${ }^{2}$ one of the most structural rights issues has largely escaped its attention for decades and remains unaddressed. The lack of interest and action at this level is problematic, as roughly half a million stateless persons reside in the

* Anne Brekoo holds a Bachelor of Arts in Liberal Arts and Sciences: Law in an International Context from University College Tilburg. She is currently pursuing an Advanced Master of Science in International Relations and Diplomacy at the University of Leiden in cooperation with the Clingendael Institute, as well as an Master of Arts in Military Strategic Studies at the Dutch Defence Academy. This article is an amended version of her Bachelor's thesis.

1 Lindsey Kingston, "A Forgotten Human Rights Crisis": Statelessness and Issue (Non)Emergence' (2013) 14(2) Human Rights Review 73. This is not to take away from the enormous effort dedicated by civil society and other organisations to raise attention for the issue. Yet, regardless of this increased attention - though not necessarily on the state level - the human impact of stateless remains the same and therefore worthy of examination.

2 See Charter of Fundamental Rights of the European Union [2000] OJ C364/01, preamble 2 ('EU Charter'). 
EU Member States. ${ }^{3}$ With the Member States holding the sovereign prerogative to regulate matters of nationality, widely diverging regulations concerning statelessness have come to exist within the EU. This hampers the provision of adequate, uniform protection for stateless person across the EU, as well as the conception of a comprehensive solution. ${ }^{4}$ At present, the EU lacks an effective overarching mechanism to address the consequences of statelessness, and is therefore limited in its ability to tackle the problem. ${ }^{5}$

In another citizenship context, however, the EU has demonstrated that it is capable of devising a framework of rights that transcends the confines of the nation state: EU citizenship. While the plight of stateless individuals - manifesting itself primarily in obstacles to the enjoyment of fundamental rights — remains unaddressed, those in possession of Member State nationality are granted rights additional to the ones they already enjoy by virtue of their national citizenship. ${ }^{6}$ It seems, therefore, that the EU finds itself in possession of a unique tool that might be capable of addressing the rights-related challenges faced by stateless individuals.

In light of the foregoing, it appears that increased action to address the impact of statelessness at the EU level would be desirable and that EU citizenship presents itself as an interesting opportunity in this regard. Explorations of the value of EU citizenship beyond its current format in the specific context of statelessness are, however, limited in number. Cognizant of this gap, such an exploration is placed at the heart of this contribution. With the aim of inspiring renewed debates on, and reconsideration of, the institution of EU citizenship as a potential approach to mitigating the human impact of statelessness, this article examines the value that EU citizenship might have for stateless persons.

This article commences, in Part II, with an exploration of the key terms that are central to this paper: 'statelessness', 'nationality' and 'citizenship'. An argument is made for the distinction between the frequently interchangeably used concepts of nationality and citizenship, as such a distinction generates new avenues to explore potential solutions to statelessness. Having set out the conceptual framework, the article arrives at its core argument in Part III. Prior to discussing the value EU citizenship for stateless individuals, however, an overview of the manifestations of statelessness in the EU, as well as an exploration of the rights attached to EU citizenship, are provided. In discussing the value of EU citizenship, a hypothetical scenario is relied upon and focus is placed on the ways in which citizenship of the EU could alleviate the hardships experienced by stateless individuals, as well as its potential to facilitate the process of nationality acquisition.

3 'Table 7: Persons under UNHCR's Statelessness Mandate' in Global Trends: Forced Displacement in 2018 (Report, UNHCR 2019) <https://www.unhcr.org/statistics/18-WRDtable-7.xls> ('UNHCR Table 7').

4 For a more detailed analysis of the protection frameworks for stateless persons existing within the European Union see, eg, Gabor Gyulai, 'Statelessness in the EU Framework for International Protection' (2012) 14(3) European Journal of Migration \& Law 279; Katia Bianchini, Protecting Stateless Persons: The Implementation of the Convention Relating to the Status of Stateless Persons across EU States (Brill 2018).

5 Such lack of a mechanism pertains not merely to the protection of stateless persons, but to the identification of stateless individuals and the avoidance of statelessness as well.

6 See Consolidated Version of the Treaty on the Functioning of the European Union, opened for signature 13 December 2007 [2012] OJ C326/47 (entered into force 1 January 2009) art 20(1) ('TFEU'). 
In an attempt to move from the hypothetical to exploring avenues for transferring these ideas into practice, Part IV provides an assessment of the potential for implementation of the hypothesised model of EU citizenship. In this context, both possibilities and limitations are highlighted. Emphasis is placed on matters such as the disentanglement of Member State nationality and EU citizenship and the competence of the EU. Having regard to the foregoing, the conclusion that derives from the analysis is posed in Part V.

\section{CONCEPTS AND DEFINITIONS: STATELESSNESS, NATIONALITY AND}

\section{CiTIZENSHIP}

It must be noted from the outset that statelessness has a variety of causes and can occur in a range of situations, meaning that hardly any two cases of statelessness are entirely comparable. Nevertheless, there is a common denominator across all cases: the lack of a nationality. A 'stateless person' is defined in art 1(1) of the 1954 Convention Relating to the Status of Stateless Persons ('1954 Convention') as 'a person who is not considered a national by any State under the operation of its law'. ${ }^{7}$ Based upon this characterisation of a stateless person, the term 'statelessness' can be understood to refer to the lack of a 'nationality'. An understanding of what the latter denotes becomes, then, essential to comprehend what the former encompasses. Unfortunately, a certain level of ambiguity and uncertainty exists in this regard, as definitive guidance on the meaning of 'nationality' remains absent from international law.

In both legal scholarship and legal provisions on these matters, 'nationality' is regularly used interchangeably with 'citizenship', suggesting that the two terms denote one and the same thing. ${ }^{8}$ However, a considerable amount of literature, inspired by questions of belonging that developments such as increased globalisation and 'Brexit' raise, has explored and argued for the distinction between the two concepts so as to accommodate transboundary possibilities for belonging. ${ }^{9}$ In aiming to illustrate the possible added value EU citizenship might have for stateless persons, this article follows suit in this trend.

Nationality, in this contribution, is taken to refer to a legal bond between an individual and a state 'having as its basis a social fact of attachment, a genuine connection of existence, interests and sentiments'. ${ }^{10}$ The possession of a nationality signifies membership of a state, indicating that a person is under the

7 Convention Relating to the Status of Stateless Persons, opened for signature 28 September 1954, 360 UNTS 117 (entered into force 6 June 1960) art 1(1).

8 See, eg, Alice Edwards, 'The Meaning of Nationality in International Law in an Era of Human Rights: Procedural and Substantive Aspects' in Alice Edwards and Laura van Waas (eds), Nationality and Statelessness under International Law (Cambridge University Press 2014) 14. Alternatively, they may be viewed as two sides of the same coin, with nationality denoting an external dimension and citizenship an internal dimension: see, eg, Paul Weis, Nationality and Statelessness in International Law ( $2^{\text {nd }}$ edn, Sijthoff and Noordhoff 1979) 4-5.

9 Kim Rubenstein and Daniel Adler, 'International Citizenship: The Future of Nationality in a Globalized World' (2000) 7(2) Indiana Journal of Global Legal Studies 519; Jonathan Fox, "Unpacking “Transnational Citizenship"” (2005) 8(1) Annual Review of Political Science 171; Dora Kostakopoulou, 'Scala Civium: Citizenship Templates Post-Brexit and the European Union's Duty to Protect EU Citizens' (2018) 56(4) Journal of Common Market Studies 854.

10 Nottebohm Case (Liechtenstein v Guatemala) (Second Phase) (Judgment) [1955] ICJ Rep 4, 23 ('Nottebohm'). Note that only part of the definition as posed by the International Court of Justice is employed here, leaving out the notion that the legal bond exists 'together with ... reciprocal rights and duties'. This is expanded upon further on in the paragraphs on 'citizenship' below. 
effective control of a government. It furthermore denotes membership of a nation, from which the term 'nationality' is inherently derivative. ${ }^{11}$ The acquisition of nationality is, with few exceptions, dependent on the presence of a genuine link between the person and the state. Its attribution is therefore generally based upon elements that demonstrate the existence of such a link, such as birth in the territory (jus soli), descent (jus sanguinis) or residence (jus domicile). ${ }^{12}$ In accordance with international law, it is the state that holds the sovereign prerogative to determine when a genuine connection is present, meaning that different modes of nationality acquisition exist depending on the state. ${ }^{13}$ Throughout Europe, particularly among EU Member States, the system of jus sanguinis is generally adhered to, though features of the jus soli system are regularly combined with the dominant jus sanguinis principle. ${ }^{14}$

Citizenship, on the other hand, encompasses an internal regime of rights, duties and privileges conferred upon individuals on the basis of membership to a particular political community, such as the state. ${ }^{15}$ It follows from this definition that 'citizenship' consists of a membership and a rights dimension. Citizenship rights, as understood for the purposes of this contribution, include not merely civil and political rights, but also encompass economic, social and cultural rights, such as the right to education, healthcare, employment and so forth. ${ }^{16}$ This extensive conception of citizenship is based on the notion that the aforementioned categories of rights - civil and political as well as economic, social and cultural rights are interdependent and interconnected. ${ }^{17}$ For instance, only by exercising one's civil and political rights, such as the right to vote or the right to petition, is a person capable of having a say in what rights hold for them. In addition to the rights dimension, citizenship may also be understood as constituting identity, which denotes the identification of an individual with other individuals in the same group based on attributes they have in common. ${ }^{18}$

Despite its local origins, citizenship has become closely attached to the state, where rights are granted to individuals because they possess nationality of a

11 Carlos Closa, 'Citizenship of the Union and Nationality of the Member States' (1995) 32(2) Common Market Law Review 487. Essentially, the term 'nationality' thus alludes to membership of a nation-state, although the term 'state' is used throughout this article for purposes of clarity.

12 Edwards (n 8).

13 Convention on Certain Questions relating to the Conflict of Nationality Laws, opened for signature 12 April 1930, 179 UNTC 89 (entered into force 1 July 1937) art 1.

14 Christian Joppke, 'Comparative Citizenship: A Restrictive Turn in Europe?' (2008) 2(1) Law \& Ethics of Human Rights 1; Caia Vlieks and Katja Swider, 'The Jus Sanguinis Bias of Europe and What It Means for Childhood Statelessness', European Network on Statelessness (Blog Post, 17 June 2015) <https:/www.statelessness.eu/blog/jus-sanguinis-bias-europe-and-whatit-means-childhood-statelessness $>$.

15 Gerard Delanty, 'Models of Citizenship: Defining European Identity and Citizenship' (1997) 1(3) Citizenship Studies 285; Rubenstein and Adler (n 9).

16 The fact that citizenship encompasses not merely political rights, but other rights as well is explicated by this statement by Nils Muižnieks: "Without citizenship, one lacks not only political rights, but often social and economic rights as well. On a symbolic level, citizenship implies being a full member of a national community, and even further, of humanity'. Nils Muižnieks 'Governments Should Act in the Best Interest of Stateless Children' Commissioner for Human Rights (Comment, 2013) <https://www.coe.int/en/web/commissioner//governments-should-act-in-the-best-interest-of-stateless-childr-1>.

17 Michael MacMillan, 'Social Versus Political Rights' (1986) 19(2) Canadian Journal of Political Science 283.

18 Engin Isin and Patricia Wood, Citizenship and Identity (SAGE 1999) ch 1; Christian Joppke, 'Transformation of Citizenship: Status, Rights, Identity' (2007) 11(1) Citizenship Studies 37. 
state. ${ }^{19}$ This is evident, for instance, from the fact that the definition of nationality as promulgated by the International Court of Justice in the Nottebohm Case (Liechtenstein $v$ Guatemala) encompasses not only the existence of a legal bond, but that of 'reciprocal rights and duties' as well. ${ }^{20}$ For the purposes of this contribution, citizenship that is granted on the basis of the existence of a legal bond is referred to as national citizenship. As it is the state that came to hold near exclusive control over citizenship, nationality has turned into a fundamental prerequisite for the acquisition of citizenship and its associated rights. ${ }^{21}$

Yet, it is reasonable to contest the assumption that the state holds a monopoly on the bestowal of citizenship. While in practice such monopoly may be the rule rather than the exception, recent developments have demonstrated that citizenship may be granted through a multitude of alternative regional and local frameworks. ${ }^{22}$ One such development is the establishment of EU citizenship, which is available to those possessing the nationality of an EU Member State and provides rights that are additional to those deriving from national citizenship:

Citizenship of the Union is hereby established. Every person holding the nationality of a Member State shall be a citizen of the Union. Citizenship of the Union shall be additional to and not replace national citizenship. ${ }^{23}$

One may derive from this formulation that it is implicitly acknowledged in the institution of EU citizenship that, albeit currently dependent on the possession of Member State nationality, a conceptual distinction between nationality and citizenship exists. ${ }^{24}$ This can be derived primarily from the fact that the terms are used to denote different forms of connection. That is, nationality is considered to refer to the bond between an individual and a (Member) State whereas citizenship describes the belonging of an individual to the European community. Furthermore, it is stated that EU citizenship is 'additional to' and shall 'not replace national citizenship'. ${ }^{25}$ In granting rights additional to those deriving from Member State nationality, citizenship of the EU refrains from encroaching upon the range of rights and duties that are traditionally associated with national citizenship. ${ }^{26} \mathrm{Put}$ otherwise, EU citizenship provides rights that national citizenship is incapable of providing and in that sense extends beyond it.

19 Roland Roth, 'Participatory Governance and Urban Citizenship' in Hubert Heinelt et al (eds), Participatory Governance in Multi-Level Context: Concepts and Experience (Springer Fachmedien Wiesbladen 2002) 75.

$20 \quad$ Nottebohm (n 10) 23.

21 Nationality may be therefore be considered an 'enabling right', allowing those whose right to a nationality has been respected to access a range of other rights, resources and freedoms. See, eg, David Owen, 'On the Right to Have Nationality Rights: Statelessness, Citizenship and Human Rights’ (2018) 65(3) Netherlands International Law Review 299.

22 Rubenstein and Adler (n 9); Damian Tambini, 'Post-National Citizenship' (2001) 24(2) Ethnic and Racial Studies 195; Saskia Sassen, 'Towards Post-National and Denationalized Citizenship' in Engin F Isin and Bryan S Turner (eds), The Handbook of Citizenship Studies (SAGE 2002). An example of a framework for citizenship that has recently revived is the city, with urban citizenship encompassing a variety of rights. See, eg, Dirk Gebhardt, 'Re-Thinking Urban Citizenship for Immigrants from a Policy Perspective: The Case of Barcelona' (2016) 20(6-7) Citizenship Studies 846).

23 TFEU (n 6), art 20.

24 It is important to emphasise that, in the current formulation, EU citizenship cannot exist independently from Member State nationality in practice.

25 TFEU (n 6), art 20.

26 Kay Hail Bronner, 'Nationality in Public International Law and European Law' in Rainer Bauböck et al (eds), Acquisition and Loss of Nationality: Policies and Trends in 15 European Countries (Amsterdam University Press 2006) 35. 
With nationality and citizenship denoting two separate things, for the purposes of this contribution and in line with broader scholarship, it becomes possible to explore additional avenues for addressing the consequences of statelessness. Rather than the state being the only actor capable of granting citizenship, which is what happens when nationality and citizenship are conflated, actors such as the EU could be granted opportunities as well. ${ }^{27}$ In light of this, one could hypothetically extend the conceptual distinction between nationality and citizenship to the institution of EU citizenship, which would come to resemble a citizenship that is no longer dependent on Member State nationality. ${ }^{28}$ As is demonstrated below, in exploring the hypothetical value of EU citizenship for stateless persons, the EU is capable of fulfilling its promise to "place the individual at the heart of its activities' and uphold its founding values of respect for 'human dignity, freedom, equality and solidarity' 29 by extending the ratione personae of EU citizenship. In doing so, this article explores not only the value of EU citizenship as it stands right now, but also of what it might and perhaps should be in the future.

\section{Statelessness in the EU AND the Potential Value of EU CitizenshiP}

\section{A Numbers and Causes}

Statelessness continues to be an invisible problem, with the people affected by it generally being described as 'legal ghosts'. ${ }^{30}$ They are typically invisible within the (legal) framework of the state, as they are not regarded a member of the national community. Because of this, as well as other issues, gathering reliable data on stateless populations remains problematic. Nevertheless, it is estimated by the United Nations High Commissioner for Refugees that of the roughly 530,000 stateless persons currently living in Europe, EU Member States are home to approximately 400,000 stateless persons. ${ }^{31}$ This means that around 75 per cent of the stateless persons living in Europe reside in an EU Member State. The general causes of statelessness are manifold, but in the EU, it most notably results from state succession, migration, and conflicts of nationality laws. These are shortly discussed below.

27 This is demonstrated in more detail in Part III.

28 There has been some careful academic consideration of the value of a revised form of EU citizenship. See, eg, Dora Kostakopoulou, 'European Union Citizenship: Writing the Future' (2007) 13(5) European Law Journal 623; Oliver Garner, 'The Existential Crisis of Citizenship of the European Union: The Argument for an Autonomous Status' (2018) 20 Cambridge Yearbook of European Legal Studies 116.

29 EU Charter (n 2) preamble 2.

30 Tamás Molnár, 'Remembering the Forgotten: International Legal Regime Protecting the Stateless Persons - Stocktaking and New Tendencies' (2014) 11(1) US-China Law Review 822.

31 UNHCR Table 7 (n 3). It is relevant to note that UNHCR's estimates are politicised in nature, and may therefore not reflect the true number of stateless persons within the EU. Other sources, such as the European Network on Statelessness and the Institute on Statelessness and Inclusion, provide estimates of the number of stateless persons in Europe as high as 600,000. See No Child Should Be Stateless (Report, European Network on Statelessness 2015) 1 $<$ https://www.statelessness.eu/sites/www.statelessness.eu/files/ENS_NoChildStateless_final .pdf >; Institute on Statelessness and Inclusion, The World's Stateless̄ (Wolf Legal Publishers 2014) 73. 
Cases of state succession have been responsible for the majority of statelessness within the EU. ${ }^{32}$ State succession essentially involves the transfer of a territory and a population from a predecessor state to a successor state; it is a transfer of sovereignty. Problems of statelessness commonly accompany such changes of sovereignty, as they necessarily involve a change of nationality for at least part of the population involved. ${ }^{33}$ In the context of state succession, statelessness arises when nationality laws adopted by the newly established states are not complementary to either the pre-existing nationality laws or to one another, with the risk that certain individuals not acquiring the nationality of either state. ${ }^{34}$ This was also the case in Europe, where in situ statelessness occurred on a substantive scale following the disintegration of the Soviet Union, the Socialist Federal Republic of Yugoslavia ('SFRY'), and the split of Czechoslovakia in the 1990s. Notably, discriminatory elements introduced in newly drafted or restored nationality laws significantly contributed to the generation of statelessness. It is for this reason that minority populations - the Roma in the cases of the SFRY and Czechoslovakia, and the ethnic Russians in Estonia and Latvia - primarily fell victim to statelessness. ${ }^{35}$

While cases of state succession have generated large in situ stateless populations in the above-described Member States, most are confronted with the problem as it arises in a migratory context. As a result of the so-called 'migration crisis' of 2015, and the entry into Europe of migrants on a massive scale, the stateless populations of a number of Member States significantly increased. ${ }^{36}$

Statelessness in a migratory context manifests itself in various ways, and can be both a cause and a consequence of migration. ${ }^{37}$ To a great extent, stateless migrants arriving in EU Member States were already without nationality prior to leaving their country of origin. Cases in point here are the stateless Kurds and Palestinian refugees from Syria. Over a period of two years, Member States

32 Olivier Willem Vonk, Maarten Peter Vink and Gerard-René de Groot, Protection against Statelessness: Trends and Regulations in Europe (Report, EUDO Citizenship Observatory 2013)

$<$ https://cadmus.eui.eu/bitstream/handle/1814/30201/eudocit_vink_degroot_statelessness_fi nal.pdf? sequence $=1 \&$ isAllowed $=\mathrm{y}>$.

33 Weis (n 8). Under international law, 'state succession' refers to the 'replacement of one State by another in the responsibility for the international relations of territory': Vienna Convention on Succession of States in Respect of Treaties, opened for signature 23 August 1978, 1946 UNTS 3 (entered into force 6 November 1996) art 2(1)(b). It is furthermore relevant to note that state succession can take various forms. See, eg, Claude Emanuelli, 'State Succession, Then and Now, with Special Reference to the Louisiana Purchase (1803)' (2003) 63(4) Louisiana Law Review 1277.

34 Kees Groenendijk, 'Nationality, Minorities and Statelessness: The Case of the Baltic States' (1993) 4(3) Helsinki Monitor 13; Laura van Waas, Nationality Matters: Statelessness under International Law (Intersentia 2008) ch 6. It derives from the notion that the nationality laws of the new states do not complement each other that statelessness in the context of state succession thus inherently results from a conflict of nationality laws.

35 For a more in-depth analysis about statelessness among ethnic Russians, see, eg, James Hughes, "Exit" in Deeply Divided Societies: Regimes of Discrimination in Estonia and Latvia and the Potential for Russophone Migration' (2005) 43(4) Journal of Common Market Studies 739. With regards to statelessness among Roma in the EU, see, eg, Jessica Parra, 'Stateless Roma in the European Union: Reconciling the Doctrine of Sovereignty Concerning Nationality Laws with International Agreements to Reduce and Avoid Statelessness' (2011) 34(6) Fordham International Law Journal 1666.

36 'Stateless Persons in Europe', Institute on Statelessness and Inclusion (Web Page, 2017) $<$ http://www.worldsstateless.org/continents/europe/stateless-persons-in-europe $>$.

37 Sophie Nonnenmacher and Ryszard Cholewinski, 'The Nexus between Statelessness and Migration' in Alice Edwards and Laura van Waas (eds), Nationality and Statelessness under International Law (Cambridge University Press 2014). 
received the asylum applications of nearly 100,000 individuals who were either stateless or of undetermined nationality, meaning statelessness was essentially 'imported' into the EU. ${ }^{38}$ Statelessness in a migratory context manifests itself in various ways, and can be both a cause and a consequence of migration. For instance, many states have provisions in their nationality laws allowing for the loss of nationality due to absence of a person from the territory for a given period of time. ${ }^{39}$ The loss or destruction of identification documents during (irregular) migration might also bring doubts as to the status of an individual, thereby potentially putting these persons at risk of statelessness. ${ }^{40}$

These large-scale situations of statelessness in the EU are significantly aggravated and perpetuated as statelessness continues into younger generations. If a child fails to acquire nationality at birth, it is possible that he or she remains stateless for years, which severely and negatively impacts the development of the child. ${ }^{41}$ To a large extent, the existence and continuation of childhood statelessness within the EU can be attributed to the general adherence by the Member States to the jus sanguinis regime. The problematic nature of this system is immediately evident, as stateless parents simply do not possess any nationality to pass on to their children. As such, rather than inheriting a nationality, a child inherits their parents' statelessness. ${ }^{42}$ Statelessness may also result from conflicts of nationality laws. Within Europe itself this is not a large problem, as there is a general jus sanguinis regime, but it particularly arises whenever parents migrate to the EU from a country that adheres to an jus soli regime. ${ }^{43}$

Without adequate safeguards in place, statelessness could thus be passed on from parent to child or result from conflicting nationality laws, leaving those children vulnerable from birth. Fortunately, safeguards are present in the nationality legislation of the majority of the Member States to ensure that children born in their territories, who would otherwise be left stateless, can acquire nationality. ${ }^{44}$ This is not to say, however, that these safeguards are adequate. For instance, in the Czech Republic, a child that would otherwise be stateless acquires Czech nationality if both parents are stateless, and at least one of them possesses

38 'Asylum and First Time Asylum Applicants by Citizenship, Age and Sex', Eurostat (Web Page, 2019) <https://ec.europa.eu/eurostat/web/productsdatasets/product?code $=$ migr_asyappctzm $>$.

39 Laura van Waas, 'The Children of Irregular Migrants: A Stateless Generation?' (2007) 25(3) Netherlands Quarterly of Human Rights 437.

40 Nonnenmacher and Cholewinski (n 37) 254. See also Addressing Statelessness in Europe's Refugee Response: Gaps and Opportunities (Report, European Network on Statelessness and Institute for Statelessness and Inclusion 2019) <https://www.institutesi.org/resources/reportaddressing-statelessness-in-europes-refugee $>$. It is further relevant, throughout the subsequent sections, to keep in mind that refugees arriving to the EU will most likely benefit more from being granted refugee status. Yet, this article continues from the assumption that for those persons that arrive in the EU and are for whatever reason unable to obtain refugee status, EU citizenship may still have value.

41 Gerard-René de Groot, 'Children, Their Right to a Nationality and Child Statelessness' in Alice Edwards and Laura van Waas (eds), Nationality and Statelessness under International Law (Cambridge University Press 2014) 144.

42 Laura van Waas (n 34), 52.

43 Migration necessarily brings with it a diversification of the nationalities and ethnicities present within a state and thereby heightens the possibility of nationality laws conflicting with one another. See Nonnenmacher and Cholewinski (n 37).

44 According to the Global Database on Modes of Acquisition of Citizenship only two countries did not provide for any safeguards for children born in the country otherwise left stateless in 2016, those being the Republic of Cyprus and Romania: see 'Global Database on Modes of Acquisition of Citizenship', GLOBALCIT (Web Page, 2017) <http://globalcit.eu/acquisitioncitizenship/>. 
a residence permit on the day the child is born. ${ }^{45}$ These requirements cannot always be fulfilled and are capable of preventing children from acquiring nationality, even though they would otherwise be left stateless. Although there is a great degree of variation across the Member State in terms of adequacy of such safeguards, examples such as these demonstrate that protection and prevention mechanisms available within the EU are far from perfect. ${ }^{46}$

\section{B EU Citizenship: Scope and Nature}

Having discussed the various manifestations of statelessness in the EU, this Part sets out the nature and scope of EU citizenship and its associated rights. This is necessary in order to generate an understanding of how these rights may mitigate the challenges faced by stateless persons.

EU citizenship was introduced by the 1993 Treaty on European Union ('Maastricht Treaty'), ${ }^{47}$ and appeared to be the cumulative result of a gradual development away from economic integration towards a more 'people-centred' EU. Although economic integration had been at the heart of the EU from the moment of its creation, it was no longer considered to be the final objective. This is evident also from the founding treaties in which, inter alia, respect for human dignity, equality and respect for the human rights of all are presently characterised as the foundational values that the EU embodies. ${ }^{48}$ In light of this, the notion that a genuine European identity was to be created, premised on the values of human rights and equality, gained traction. It was for the purpose of creating such a common identity, therefore, that EU citizenship emerged. ${ }^{49}$ Having been subjected to numerous revisions over the years, the right to EU citizenship is now firmly established in the founding treaties:

Citizenship of the Union is hereby established. Every person holding the nationality of a Member State shall be a citizen of the Union. Citizenship of the Union shall be additional to and not replace national citizenship. ${ }^{50}$

The status, currently available only to those holding Member State nationality, is accompanied by a set of rights which are additional to the rights deriving from national citizenship. These are laid down in art 20(2) of the Treaty on the Functioning of the European Union ('TFEU'), and their substance is further set out in arts 21-24 TFEU as well as ch V of the Charter of Fundamental Rights of

45 Act on Citizenship of the Czech Republic and on the Amendment of Selected Other Laws (Czech Republic) Act No 186/2013 of 2013, s 5.

46 This was confirmed by, eg, Gyulai (n 4); Bianchini (n 4). See also Laura van Waas, 'Statelessness: A 21st Century Challenge for Europe' (2009) 20(2) Security and Human Rights 133.

47 Treaty on European Union, opened for signature 7 February 1992 [1992] OJ C 224, 1 (entered into force 1 November 1993) ('Maastricht Treaty').

48 Consolidated Version of the Treaty on European Union, opened for signature 13 December 2007 [2012] OJ C326/13 (entered into force 1 January 2009) art 2 ('TEU'). See also Gerhard van der Schyff, 'EU Member State Constitutional Identity: A Comparison of Germany and the Netherlands as Polar Opposites' (2016) 76 ZaöRV 167; Oliver Mader, 'Enforcement of EU Values as a Political Endeavour: Constitutional Pluralism and Value Homogeneity in Times of Persistent Challenges to the Rule of Law' (2019) 11(1) Hague Journal on the Rule of Law 133.

49 Patricia Mundus, European Citizenship after Brexit: Freedom of Movement and Rights of Residence (Palgrave MacMillan 2017) ch 2. See also Willem Maas, 'European Union Citizenship in Retrospect and Prospect' in Engin Isin and Peter Nyers (eds), Routledge Handbook of Global Citizenship Studies (Routledge 2014).

$50 \quad T F E U(\mathrm{n} 6)$ art 20. It is furthermore confirmed in TEU (n 48) art 9. 
the European Union ('EU Charter'). ${ }^{51}$ Among the rights attached to EU citizenship is the right to participate in European Parliament and municipal elections in the Member State of residence, as well as the right to submit a complaint to the European Ombudsman, petition to the European Parliament, and communicate with the EU institutions. ${ }^{52}$ EU citizens are further entitled to receive protection in a third-country, in which the Member State of nationality is unrepresented, from the diplomatic and consular authorities of any of the Member States on equal terms with the protection afforded to the nationals of that state. ${ }^{53}$ Moreover, citizens of the EU that are engaged in or seek employment in one of the Member States enjoy the right of non-discrimination on the basis of nationality (or the lack thereof) as 'regards employment, remuneration and other conditions of work and employment'. 54 This is complemented, as contained in art 7 of Regulation $492 / 2011,55$ by a right to be treated equally in receiving social and tax advantages as well as in accessing vocational training.

Lastly, and considered the cornerstone of EU citizenship rights by most, EU citizens are granted the right to 'move and reside freely within the territory of the Member States'. ${ }^{6}$ Under EU law, and specifically Directive 2004/38/EC ('Free Movement Directive'), free movement and residence rights are available to various categories of citizens, ranging from the economically active to the economically inactive. ${ }^{57}$ The scope of the rights enjoyed depends on the classification of the individual. The right of (legal) residence is restricted to three months for economically inactive citizens of the EU, but may be extended beyond this for semi-economically, including students and persons of independent means, and economically active citizens. The latter category, consisting of workers and the self-employed, have additional rights of movement and residence for the purpose of employment or establishment. ${ }^{58}$ In the instance that the period of legal residence in a Member State exceeds five years, the EU citizen is entitled to a permanent residence permit in that Member State, regardless of the capacity in which that person has been able to reside for five years. ${ }^{59}$ Put otherwise, the right to permanent residence is available for all EU citizens, and their family members, whether they are economically active or not, as long as they have legally resided in that Member State for five years.

51 EU Charter (n 2).

52 TFEU (n 6) arts 20(2)(b), (d).

53 ibid art 20(2)(c).

54 ibid art 45(2).

55 Regulation No 492/2011 on Freedom of Movement for Workers within the Union [2011] OJ L141/1.

56 TFEU (n 6) art 20(2)(a).

57 Directive 2004/38/EC on the Right of Citizens of the Union and Their Family Members to Move and Reside Freely within the Territory of the Member States [2004] OJ L 158/77 ('Free Movement Directive').

58 Kathrin Hamenstädt, 'The Impact of the Duration of Lawful Residence on the Rights of European Union Citizens and Their Third-Country Family Members' (2017) 24(1) Maastricht Journal of European and Comparative Law 63.

59 Free Movement Directive (n 57) art 16(1). For further information, see Elspeth Guild, Steve Peers and Jonathan Tomkin, The EU Citizenship Directive: A Commentary ( $2^{\text {nd }}$ edn, Oxford University Press 2019). 


\section{The Impact of Statelessness and the Value of EU Citizenship}

Those that are granted EU citizenship on the basis of Member State nationality find themselves in a privileged position: they are able to benefit from rights made available to them through national citizenship and EU citizenship. Stateless persons find themselves on the opposite end of the spectrum when it comes to the enjoyment of rights. Those belonging to the vast stateless population living in the EU, like most individuals lacking a nationality, generally find themselves unable to enjoy a large number of rights and face additional hardships as a result of discrimination, marginalisation and social exclusion. These rights-related challenges may be attributed to the fact that nationality acts as an enabling right. ${ }^{60}$ With Member State nationality further constituting a prerequisite for the grant of EU citizenship, stateless persons, unsurprisingly, are unable to enjoy the additional rights attached to it under the current formulation of EU citizenship. Yet, it is precisely the grant of these rights that could be beneficial for stateless persons and facilitate nationality acquisition in one of the Member States.

To explore the potential benefits of EU citizenship to stateless persons in greater detail, please consider the following hypothetical scenario. Following academic calls and successful lobbying for a separation of EU citizenship and Member State nationality, a revision of the ratione personae of EU citizenship has been approved. The second sentence of art 20(1) TFEU now reads that EU citizenship shall be conferred upon every person holding the nationality of a Member State and, in the absence of such nationality, upon every person declared an EU citizen. ${ }^{61}$

In light of this newly autonomous nature of EU citizenship, the necessary competences to regulate its acquisition have furthermore been conferred upon the EU, which it previously lacked. ${ }^{62}$ The acquisition of the status has been conditioned upon legal residence of a period of five years in the territory of one of the Member States to demonstrate the existence of a genuine connection. ${ }^{63}$ This residency requirement may be eased for those that have been identified as

60 Owen (n 21). See also van Waas (n 34).

61 The essence of this proposed treaty revision was originally suggested by Dora Kostakopoulou, 'Who Should be a Citizen of the Union? Toward an Autonomous European Union Citizenship'Verfassungsblog (Blog Post, 16 January 2019) < https://verfassungsblog.de/whoshould-be-a-citizen-of-the-union-toward-an-autonomous-european-union-citizenship/>. It must further be noted that the model of EU citizenship as theorised here would not only benefit stateless persons, but may also be granted to third-country nationals ('TCNs') that have resided in the territory for the required period of time. However, it is recognised that EU citizenship has added value specifically for stateless persons as, unlike TCNs, they do not possess national citizenship rights to rely upon.

62 A more detailed discussion of (the lack of) EU competences in the area of nationality and citizenship is provided in Part 4(A).

63 Residency on the territory presents an obvious method of demonstrating the existence of such a connection in light of the various modes of nationality acquisition which have shortly been set out in Part II. These modes are generally illustrative of a genuine connection and residency (jus domicile) is the one option that remains in the absence of the links that could be acquired through birth on the territory (jus soli) or ancestral relations (jus sanguinis). 
'stateless', in line with a common statelessness determination procedure set up by the EU, to two years of habitual residence. ${ }^{64}$

With the institution of EU citizenship no longer tied to Member State nationality, stateless persons would hypothetically be able to benefit from the rights attached to citizenship of the EU in several respects. First and foremost, stateless persons would be able to legally reside in a Member State having been granted the status of 'EU citizen', which is both directly and indirectly beneficial. Residency rights are unconditionally available to nationals of a state, leaving stateless persons with the requirement of obtaining a residence permit. For a variety of reasons, among which are difficulties in producing identification documents, it may be difficult for stateless persons to obtain a residence permit and achieve legal residence. ${ }^{65}$ The lack of such legal residence and the irregular presence on the state's territory make insecurity and fear an everyday reality for stateless individuals. ${ }^{66}$ Fear of arrest, detention or even expulsion when state authorities discover their irregular presence or lack of identification documents leave stateless persons hesitant to engage in activities that require them to get involved with such authorities. As a corollary to the lack of legal residency, stateless persons furthermore find themselves unable to exercise their right to free movement, both domestically and internationally. ${ }^{67}$ It goes without saying that EU citizenship, especially with its accompaniment of freedom of cross-border movement and residence, has the potential of directly resolving the issue of legal residence. This would provide stateless individuals with increased security regarding their residency, as well as increased confidence in their presence on the territory. It furthermore has the potential to prevent them from being detained or expelled on grounds of illegal residence.

Access to government and public services, such as health care and quality education, may also be facilitated through the grant of legal residence. In the absence of a nationality, legal residence commonly constitutes a prerequisite for admission to educational and healthcare facilities, and prevents individuals from

64 This is in line with international law. See, eg, Convention on the Reduction of Statelessness, opened for signature 30 August 1961, 989 UNTS 185 (entered into force 13 December 1975) art 1(2)(b). The easing of this legal residency requirement also serves to prevent the emergence of the following paradox: EU citizenship is expected to be beneficial because it could provide stateless individuals with legal residence (see below), but proof of legal residence constitutes a requirement for eligibility for EU citizenship.

65 No Country of One's Own: An Advisory Report on Treaty Protection for Stateless Persons in the Netherlands (Report, Advisory Committee on Migration Affairs 2014) $<$ https://www.adviescommissievoorvreemdelingenzaken.nl/binaries/adviescommissievoorvr eemdelingenzaken/documenten/publicaties/2014/09/11/no-country-of-one $\%$ E2\%80\%99sown/No_country_of_ones_own_ACVZ_report_20140911.pdf >. See also Caroline Sawyer and Brad Blitz, Statelessness in the European Union: Displaced Undocumented, Unwanted (Cambridge University Press 2011).

66 'This Is Our Home': Stateless Minorities and Their Search for Citizenship (Report, UNHCR 2017)

$<$ https://www.unhcr.org/ibelong/wpcontent/uploads/UNHCR_EN2_2017IBELONG_Report_ePub.pdf >. In an interview conducted with a stateless person living in the Netherlands, it was noted that this could even mean that stateless persons '...do not make an attempt to have themselves registered as "stateless" because they are afraid of expulsion or imprisonment', even though they could be granted additional rights on the basis of this status. Interview with Lena, a stateless person living in the Netherlands (Anne Brekoo, Tilburg, 27 February 2019)). The author has obtained permission to include excerpts of the interview in this article.

67 van Waas (n 34) ch 10. 
having to pay potentially high costs. ${ }^{68}$ Hence, stateless individuals that do not legally reside within a state's territory may face obstacles in accessing health care and obtaining an adequate level of education. ${ }^{69}$ This latter hardship, in turn, has consequences that extend into adulthood, particularly when it comes to employment. For stateless persons that are unable to enjoy quality education, prospects of engaging in meaningful employment decrease accordingly. Access to employment is further complicated by requirements of work permits or identification documents to enter into employment contracts. ${ }^{70}$ The hypothetical grant of EU citizenship has the potential, through its right to legal residence, to remove the obstacles faced by stateless persons in accessing healthcare, education, and meaningful employment. EU citizenship may serve as a means of identification and legal residence may assist stateless persons in fulfilling requirements for access.

All of the above could, theoretically, just as easily be achieved by the grant of residency rights to stateless persons. However, the conferral of EU citizenship status has benefits that extend beyond this, and may also provide access to other rights and resolve additional hardships. An example of one such right is the right to political participation; a right from which stateless persons have traditionally been excluded. ${ }^{71}$ The grant of EU citizenship has the potential of allowing stateless individuals to vote and stand candidate in both municipal and European Parliament elections, and thereby have a say in decisions that concern them. ${ }^{72}$ Furthermore, stateless persons would be entitled to receive protection from consular and diplomatic authorities abroad. Prior to the advent of EU citizenship, Member States reserved the right to consular and diplomatic protections to their national citizens and thus prevented stateless individuals from receiving such protection. ${ }^{73}$ The advent of EU citizenship changed this, allowing individuals to benefit from a state's consular and diplomatic protection abroad even if they lack that state's nationality.

Stateless persons also frequently fall victim to discrimination. This discrimination is already present in the fact that those lacking a nationality are restricted in their access to a number of rights, such as education and health care. As is noted above, the grant of EU citizenship, and its associated residency rights, is capable of facilitating equal access to these rights. In the context of employment, stateless persons may further benefit from workers' rights. In the instance that a

68 See, eg, Román Romero-Ortuño, 'Access to Health Care for Illegal Immigrants in the EU: Should We Be Concerned?' (2004) 11(3) European Journal of Health Law 245; Gareth Davies, 'Higher Education, Equal Access, and Residence Conditions: Does EU Law Allow Member States to Charge Higher Fees to Students Not Previously Resident?' (2005) 12(3) Maastricht Journal of European and Comparative Law 227.

69 I Am Here, I Belong: The Urgent Need to End Childhood Statelessness (Report, UNHCR $2015)<\mathrm{https}$ //www.unicef.org/protection/files/FINAL_ENGLISH_PDF.pdf>.

70 See, eg, Lindsey Kingston and Kathryn Stam, 'Recovering from Statelessness: Resettled Bhutanese-Nepali and Karen Refugees Reflect on the Lack of a Legal Nationality’ (2017) 16(4) Journal of Human Rights 389.

71 Indira Goris, Julia Harrington and Sebastian Köhn, 'Statelessness: What It Is and Why It Matters' (2009) 32 Forced Migration Review 4.

72 EU Charter (n 2) art 39.

73 See art 5 of the Vienna Convention on Consular Relations, in which it is repeatedly emphasised that consular functions consist in the protection (of the interests) of nationals of the sending state in the territory of the host state. Vienna Convention on Consular Relations opened for signature 24 April 1963, 596 UNTS 261 (entered into force 19 March 1967). See also Bronwen Manby, Citizenship and Statelessness in Africa: The Law and Politics of Belonging (Wolf Legal 2015) ch 2. 
stateless person is able to overcome the abovementioned obstacles to engaging in meaningful employment, their lack of a nationality could leave them vulnerable to exploitation and discrimination. For example, they may be denied access to social security, such as pension entitlements and other forms of state support, leaving them in an uncertain situation when they leave their jobs. ${ }^{74}$ Having been granted EU citizenship, these issues would effectively be resolved, as the treaties and secondary legislation prohibit any discrimination on the basis of nationality (or the lack thereof in this case), with regard to access to employment, remuneration, and so forth. ${ }^{75}$ It would further allow the stateless to claim benefits on equal terms as nationals of the Member State, which provides a form of protection if the employment relationship ceases to exist.

Discriminatory treatment of stateless persons has consequences that are additional to preventing access to basic services and rights. They may be viewed and treated as 'outsiders' or 'others', which, in the instances where historically disadvantaged minority groups are the victims of statelessness, is capable of institutionalising discrimination. ${ }^{76}$ The lack of nationality and citizenship is, as such, capable of affecting a person's sense of belonging within a community and can generate identity issues. ${ }^{77}$ The provision of EU citizenship has the potential of increasing the feeling of belonging to a community and contribute to resolving identity issues deriving from the lack of a nationality, due to the identity dimension of citizenship.

The implications of granting EU citizenship to stateless persons extend beyond the mitigation of the abovementioned rights-related challenges and other hardships, as it has the potential of indirectly facilitating the acquisition of nationality through regular naturalisation procedures. For example, a period of legal residence is generally among the requirements for acquisition of nationality through naturalisation. ${ }^{78}$ On the basis of being granted EU citizenship status, stateless persons would be able to legally reside within the EU for up to three months without any additional requirements. ${ }^{79}$ The length of this legal residence can be extended to five years if a person engages in economic activity or intends do so, which may eventually result in the acquisition of a permanent residence permit. The ability to legally reside would thus simplify meeting this requirement for naturalisation.

74 Laura van Waas, Addressing the Human Rights Impact of Statelessness in the EU's External Action (Report, European Parliament 2014) $<$ http://www.europarl.europa.eu/RegData/etudes/STUD/2014/534983/IPOL_STU\%282014 $\% 29534983$ EN.pdf>.

75 TFEU (n 6) art 45(2); Free Movement Directive (n 57) art 7.

76 Institute on Statelessness and Inclusion (n 31).

77 Zelda van der Velde and Rianne Letschert, 'Collective Victimisation of Stateless Peoples: The Added Value of the Victim Label' (2014) 19(1-2) Tilburg Law Review 285; Kristy Belton, 'Rooted Displacement: The Paradox of Belonging among Stateless People' (2015) 19(8) Citizenship Studies 907.

78 See Part II, on the discussion of various ways of nationality acquisition.

79 It must be noted that the presence of an interstate element - that is, movement across Member State borders - constituted a prerequisite for the enjoyment of these rights under EU law. As such, in situations confined to a single Member States, EU citizens would thus not be able to rely on EU law to claim their rights. In the case Gerardo Ruiz Zambrano $v$ Office National de l'Emploi (ONEm), however, the Court ruled that EU citizens could rely on TFEU (n 6) art 20 to claim their rights, even if no cross-border element was present: Gerardo Ruiz Zambrano v Office National de l'Emploi (ONEm) (Case C-34/09) [2011] ECR I-01177. The lack of interstate movement therefore does not necessarily pose an obstacle to the enjoyment of citizens' rights such as the right of residence. 
Employment of stateless persons as a result of being granted EU citizenship is also capable of facilitating the naturalisation process. For instance, sufficient knowledge of the national language is often posed as a requirement to naturalise, but might bring associated costs with it to receive training or to take a language test. ${ }^{80}$ Naturally, unemployed (stateless) persons might struggle to gather the funds and therefore be unable to acquire a nationality. Earning a wage would work towards solving this problem. What the above intends to illustrate is that EU citizenship, hypothetically, is capable of not only mitigating the practical problems encountered by stateless individuals, but also of indirectly helping them attain the 'genuine connection' with a Member State that is necessary to eventually acquire nationality and hence national citizenship.

Based on the above analysis, it appears that the EU - through the grant of EU citizenship to stateless persons - can contribute to the facilitation of their naturalisation in their state of residence. This facilitation of naturalisation does not necessarily infringe upon the Member States' competences and sovereign prerogative to regulate nationality matters. While the hypothetical scenario envisages EU competences necessary to regulate the conditions for acquisition of EU citizenship, the EU must be cognizant and respectful of the competences of the Member States in doing so. Competence encroachment can be avoided in this instance, because, although the possession of EU citizenship could significantly expedite the process of nationality acquisition, the determination of what constitutes a 'genuine link' and what requirements are to be met to obtain nationality would remain with the Member States. After all, the EU would not demand the Member States alter their rules regarding nationality acquisition or ease their requirements. As such, a stateless person might be granted EU citizenship and, for instance, acquire a residence permit, but if that person does not meet the requirements set by the Member State, they will be unable to acquire its nationality. It must be clear that EU citizenship in such a context would not serve as a replacement of national citizenship or nationality, but rather provides a gateway for stateless persons to acquire nationality of one of the Member States through channels that are generally available for anyone, such as naturalisation.

As the above has demonstrated, citizenship of the EU has the potential of significantly alleviating several of the rights-related challenges and additional hardships experienced by stateless persons. This analysis, however, relied upon the assumption that the ratione personae of EU citizenship was expanded to include a range of other beneficiaries, most notable of which are stateless individuals. The value of EU citizenship in this context therefore derives not so much from what it currently embodies, but rather from what it could be. It appears that the institution of EU citizenship could be more inclusive, more respectful of human rights, and thereby more considerate of the individual. If the aim of the EU is to truly place the 'individual at the heart of its activities', and EU citizenship is envisaged as the means of doing so, a reconsideration of the nature of the institution as it currently stands appears to be in place.

80 Asaf Levanon and Noah Lewin-Epstein, 'Grounds for Citizenship: Public Attitudes in Comparative Perspective' (2010) 39(3) Social Science Research 419; Harald Bauder, 'Domicile Citizenship, Human Mobility and Territoriality' (2014) 38(1) Progress in Human Geography 91. 


\section{Moving FROM the HypotheticAl to REALITY: An ASSESSMENT}

The hypothetical scenario presented above relies upon two major assumptions in exploring the value of EU citizenship for stateless persons: that the grant of EU citizenship is no longer dependent on the possession of nationality and that the EU possesses the necessary competences to legislate in this area. The former assumption is relatively straightforward. In its present form, nationality of a Member State constitutes a prerequisite for acquisition of EU citizenship. The grant of EU citizenship to individuals that do not meet this requirement, such as stateless persons, is therefore impossible unless the presently interlinked statuses of Member State nationality and EU citizenship are disentangled. The reasons underlying the second assumption, although already shortly touched upon throughout the article, are slightly more complex. Therefore, a discussion of the division of competences in the EU is provided prior to examining the possibilities for and obstacles to realising the hypothetical scenario.

\section{A The Competence Question}

The realisation of the hypothesised design of EU citizenship does not merely require a disentanglement of nationality and citizenship, but also requires the EU to possess the competence to legislate in this area. The term 'competence' refers to the legal authority held by the EU or, in other words, the power to adopt legally binding acts. ${ }^{81}$ The division of competences between the EU and its Member States is governed primarily by the principle of conferral, as is specified in art 5(1) of the Treaty on European Union ('TEU'). ${ }^{82}$ According to this principle, the EU may only act and legislate insofar the Member States have 'transferred' some of their sovereign legislative powers to the EU. Its competences are, in that sense, not 'inherent', as it only possesses those competences conferred upon it by the treaties. ${ }^{83}$

The founding treaties of the EU provide a classification of competences, distinguishing between exclusive, shared and ancillary competences. ${ }^{84} \mathrm{In}$ the areas where the EU has an exclusive competence it is the only entity that may legislate, excluding the Member States from exercising legislative powers. ${ }^{85}$ If the EU shares a competence with the Member States, both the Member States and the EU are allowed to adopt legally binding acts. However, the Member States may only exercise that competence when the EU has not yet done so. ${ }^{86}$ The power of the EU is most limited in areas where it holds an ancillary competence, since it can than only 'carry out actions to support, coordinate or supplement actions of the Member States'. ${ }^{87}$ In such cases, the main competence to legislate resides with the Member States, taking a form similar to an exclusive competence, as the EU is merely allowed to complement Member State action.

81 Kieran Bradley, 'Legislating in the European Union' in Catherine Barnard and Steve Peers (eds), European Union Law (2 ${ }^{\text {nd }}$ edn, Oxford University Press 2017) 105.

$82 T E U$ (n 48).

83 Alan Dashwood, 'The Relationship Between the Member States and the European Union/European Community’ (2004) 41(1) Common Market Law Review 355.

84 To that effect, see TFEU (n 6) Title II on 'Categories and Areas of Union Competence'; TEU (n 48) arts 4, 5.

$85 T E U(\mathrm{n} \mathrm{48)}$ art 2(1); TFEU (n 6) art 3.

$86 T E U(\mathrm{n} \mathrm{48)}$ arts $2(2), 4$.

87 TFEU (n 48) arts 2(5), 6. 
While there is no explicit mention of EU competence in matters of nationality or citizenship in the treaties, an exclusive competence on part of the Member States in nationality matters can be derived from a number of things. Primary evidence for limited EU competence can be found in art 4(2) TEU, based on which the EU undertakes to respect the equality of Member States as well as their national identities. An essential element of such national identities is, as Advocate General Poiares Maduro observed in his opinion in Janko Rottmann v Freistaat Bayern ('Rottmann'), the 'composition of the national body politic'. ${ }^{88}$ With the Member States, by law and by principle, exercising exclusive control over matters of nationality and the EU under an obligation to respect their right to delimit the composition of their body politic, it goes without saying that the EU would violate its obligations if it imposed restrictions on nationality regulations.

Furthermore, the introduction of EU citizenship by the Maastricht Treaty was accompanied by the Member States' articulation of the wish to retain sovereignty in nationality matters in Declaration on Nationality of a Member State annexed to the TEU ('the Declaration'). ${ }^{89}$ It held that 'the question whether an individual possesses the nationality of a Member State shall be settled solely by reference to the national law of the Member State concerned'. ${ }^{90}$ Although the Declaration was removed from the official treaty text with the coming into force of the Treaty of Lisbon in 2009, ${ }^{91}$ it continues to be an authoritative source of reference in current case law and is regularly looked back upon for guidance. ${ }^{92}$ Settled case-law sets out the exclusive competence on nationality matters held by the Member States, with the Court of Justice of the European Union ruling on several occasions that 'it is for each Member State ... to lay down the conditions for the acquisition and loss of nationality'. ${ }^{93}$

In essence, the above confirms what has been established in international law and what is customary within the international community: that it is up to the (Member) state to determine who they consider to be their nationals, and who continues to be so. It is by laying down such rules that a (Member) state defines its 'people' and delimits its national body politic. It follows from this that the EU is left with only ancillary competences in the area of nationality and citizenship specifically.

\section{B Realising a Reformed EU Citizenship: Possibilities and Obstacles}

It is possible to conclude from the above that both a disentanglement of Member State nationality and EU citizenship, as well as a broadening of EU competences,

88 Janko Rottmann v Freistaat Bayern [2010] (C-135/08) ECR I-01449, [25] (AG Poiares Maduro).

89 Maastricht Treaty (n 47) annex ('Declaration on Nationality of a Member State [1992] OJ C191/98').

90 ibid.

91 Treaty of Lisbon Amending the Treaty on European Union and the Treaty establishing the European Community, opened for signature 13 December 2007 [2007] OJ C306/1 (entered into force 1 January 2009).

92 See, eg, Janko Rottmann v Freistaat Bayern [2010] (C-135/08) ECR I-01449, [3], in which the Court includes Declaration No 2 (n 82) as a relevant provision of EU legislation.

93 Micheletti v Delegación del Gobierno en Cantabria [1992] (C-369/90) ECR I-4339, [10]; Belgian State v Fatna Mesbah [1999] (C-179/98) ECR I-07955, [29]; The Queen v Secretary of State for the Home Department, ex parte: Manjit Kaur [2001] (C-192/99) ECR I-1237, [19]; Kunqian Catherine Zhu v Secretary of State for the Home Department [2004] (C-200/02) ECR I-09925, para 37. 
must be achieved in order to reform EU citizenship to achieve the hypothesised benefits. Because the treaties currently do not provide for either, several substantive changes to the current provisions of EU law are required.

This particularly holds true for both the founding treaties as well as relevant secondary legislation, such as the Free Movement Directive and the EU Charter, as these currently condition the acquisition of EU citizenship upon the possession of Member State nationality. The Treaties themselves provide for both simplified and ordinary revision procedures, although the former only provides for limited changes based on the nature of the change and are therefore unlikely to provide a basis for treaty revision for EU citizenship. ${ }^{94}$ Yet, under the ordinary revision procedure, any amendments regarding the material content of the treaties may be proposed by the European Parliament, Commission or any of the Member States. ${ }^{95}$ This includes proposals for expanding the scope of EU citizenship as well as the competences of the EU. Acting on a simple majority, the European Council determines whether or not to set the procedure into motion, and will convene a convention consisting of Member State representatives and Commission members, which will decide the fate of the proposed revision by consensus. ${ }^{96}$ While there appears to be an opportunity for the EU to amend the treaties so as to allow for the grant of EU citizenship to stateless persons, an obstacle presents itself in the extensive involvement of the Member States. Because EU interference in affairs of nationality and citizenship has previously sparked controversy among the Member States, reaching the consensus required for revision remains improbable. ${ }^{97}$

Considering the previous analysis, it appears that the legal modifications required for the EU to grant EU citizenship to stateless persons would call for significant political will and a creative and a flexible approach; something that may be difficult to achieve in the near future. However, these current obstacles to the implementation of the hypothesised measure should not, and do not, undermine the potential of EU citizenship to mitigate the impact of statelessness as well as fostering European integration and greater inclusion.

\section{CONCLUSION}

It is noted in the preamble to the EU Charter that, with the establishment of the institution of EU citizenship, the EU placed the individual at the heart of its activities. Indeed, in devising a framework of rights that transcends national boundaries, detached from economic objectives, a certain class of individuals came to occupy a privileged position within the EU: those in possession of the nationality of one of the Member States. In conditioning the grant of EU citizenship upon the possession of such nationality, this extraordinary framework of rights has acquired an exclusionary nature. The roughly half a million stateless individuals - who are unable to derive rights from any form of national or other citizenship - residing in the Member States of the EU, are unable to benefit from all that this institution has to offer. And yet, the value of EU citizenship may be

94 Bradley (n 81).

$95 T E U(\mathrm{n} 48)$ arts 48(2)-(5).

96 Bradley (n 81).

97 Mark Dawson, 'The Political Face of Judicial Activism: Europe's Law-Politics Imbalance' in Mark Dawson, Bruno de Witte and Elise Muir (eds), Judicial Activism at the European Court of Justice (Edward Elgar 2013). 
found precisely in its ability to grant those individuals the rights they are in dire need of.

This article has demonstrated that the rights attached to EU citizenship are capable of significantly mitigating the challenges and hardships experienced by stateless individuals. The grant of EU citizenship has the potential of simplifying access to legal residence, education, healthcare, meaningful employment and so forth. Furthermore, it could considerably facilitate the naturalisation process for those individuals by assisting them in attaining the required 'genuine connection' to one of the Member States. What is significant about this proposal is that, building on the assumption that the EU has acquired the necessary competences to legislate, the EU can avoid encroaching upon either the competences or the sovereign prerogatives of Member States in nationality matters. In granting EU citizenship to stateless persons there is, after all, no need for the EU to interfere in matters of nationality or national citizenship. It remains up to the Member States to determine the grounds upon which national citizenship may be granted. Separating 'nationality' and 'citizenship' — both conceptually and legally — is essential in this context. With the state no longer possessing the exclusive ability to resolve nationality-related problems, one can imagine an alternate reality in which the EU could be capable of achieving the provision of rights and the facilitation of naturalisation processes without overstepping.

It is recognised that there are numerous obstacles to overcome in moving from the hypothetical to reality, not in the least an amendment of the founding treaties. The value of EU citizenship, specifically in the context of statelessness, therefore, derives not from what it currently is, but from what it could be in the future. By extending EU citizenship rights to a population more in need of rights than any other, the institution of EU citizenship has the potential of being more inclusive, more respectful of human rights, and thereby more considerate of the individual. If the aim of the EU is truly to place the interests of the individual at its core and to uphold its values of respect for freedom, solidarity, equality and human dignity, the abovementioned proposal seems worthy of its consideration. Hopefully, then, this article is taken as an opportunity by scholars and practitioners to further explore the value of EU citizenship and to consider it as a possible solution when debates on nationality and citizenship have evolved to such an extent that solutions such as these become feasible. 